\title{
Nanoporous Silicon-Based Direct Hydrochloric Acid Fuel Cells
}

\author{
T.D. Dzhafarov ${ }^{1, *}$ and S. AydinYuksel ${ }^{2}$ \\ ${ }^{1}$ Institute of Physics, Azerbaijan National Academy of Sciences, Az-1143 Baku, Azerbaijan \\ ${ }^{2}$ Department of Physics, Yildiz Technical University, 34210 Esenler/lstanbul, Turkey
}

\begin{abstract}
Fabrication and characterization of Au/Porous silicon/Silicon (Au/PS/Si)-type direct hydrochloric acid fuel cells have been presented in this work. The Au/PS/Si cells were prepared by first creating the nanoporous silicon layer in single-crystalline Si using the anodic etching under illumination and deposition Au catalyst layer onto the porous silicon. The porous silicon filled with hydrochloric acid was developed as a proton conducting membrane. Using $\mathrm{HCl}: \mathrm{H}_{2} \mathrm{O}(1.7 \mathrm{M})$ solution as fuel the open circuit voltage of $0.65 \mathrm{~V}$ was obtained and maximum power density of $3.5 \mathrm{~mW} / \mathrm{cm}^{2}$ at room temperature was achieved. It is shown that the Au/PS/Si-type direct hydrochloric acid fuel cell with gold catalyst operating at room temperature can be considered as the most promising type of low cost fuel cell for small power-supply units.
\end{abstract}

Keywords: Porous silicon membrane, $\mathrm{HCl}$ electrolyte, gold catalyst, power density, open circuit voltage.

\section{INTRODUCTION}

Nowadays, the demand for clean and renewable energy sources for the rapidly growing portable electronics market (mobile electronic devices, telecommunication, military equipment, etc.) attracts the attention of many research centers. The direct methanol fuel cell (DMFC) based on proton exchange membrane (PEM) with organic polymer membrane (Nafion $\AA$ ), as proton conductor, which uses liquid methanol is considered as the promising type of fuel cell for small power-supply units [1]. The fabrication of most portable electronic devices is based on standard micro-fabrication technique, but PEM type fuel cells with polymer membrane are not readily integrated with this technique. Taking the above into consideration, it would be desirable to develop a solid state proton conducting membrane and fuel cell technology compatible with standard micro-fabrication techniques. The crystalline structure of porous silicon presents a network of silicon in nano (micro)-sized regions with an extremely large surface-to-volume ratio (up to 800 $\left.\mathrm{m}^{2} / \mathrm{cm}^{3}\right)$. The structure of porous silicon is like a sponge or columnar where quantum confinement effects play fundamental role. The pore surfaces are covered by silicon hydrides $(\mathrm{Si}-\mathrm{H})$ and silicon oxides (Si-O). Existence of pores, especially the canal-form pores, which determine large ion (proton) conductivity along the pores opens new perspectives for using porous silicon-based structures as hydrogen fuel cells [2].

Chiefly, previous works on fuel cells using the porous silicon have been focused on direct methanol

*Address correspondence to this author at the Institute of Physics, Azerbaijan National Academy of Sciences, Az-1143 Baku, Azerbaijan; Tel: +99412 5393725; Fax:+99412 5470456; E-mail:caferov@physics.ab.az fuel cell. Traditionally, platinum group metals $(\mathrm{Pt}, \mathrm{Pt}-$ $\mathrm{Ru}, \mathrm{Pt}$-Ir alloy, $\mathrm{RuO}_{2}$ and $\mathrm{Pd}$ ) have been employed as the most effective catalysts within most types of low temperature fuel cells including those with polymer electrolytes [3, 4]. The membranes in these fuel cells become highly acidic during operation, demanding the use of corrosion resistant construction materials and platinum group metal catalysts.

Present study demonstrated that the direct fuel cell with nanoporous silicon layer as proton conducting membrane, aqueous hydrochloric acid as fuel and gold catalyst film (Hydrochloric Acid Fuel Cell-HCAFC) is interesting for micro power generation. HCAFC have suggested as an alternative to DMFC. In $\mathrm{HCl}$ fuel cell, oxygen is substituted by chlorine as the oxidizing agent. Hence the product from this fuel cell is not water, but hydrogen chlorine. The use hydrochloric acid fuel cells in industries where chlorine is produced as a by-product, e.g. in magnesium and sodium electrolysis, can also be beneficial. Only a few papers on hydrogenchlorine fuel cells with Nafion membrane are available together with a handful of registered patents [5-7]. Data on properties of $\mathrm{Au} / \mathrm{Porous}$ silicon-based fuel cells with sodium borohydride and hydrogen sulphide solutions as fuel were early published $[8,9]$.

\section{Experimental}

Porous silicon layers with thickness of $10-20 \mu \mathrm{m}$ and average porosity from 40 to $80 \%$ were prepared on n-type (111) Si substrates $\left(\rho=1 \times 10^{-4} \Omega\right.$.m) by anodic etching in a HF: $\mathrm{H}_{2} \mathrm{O}$ solution under the white light illumination [10]. For some measurements the PS films were then detached from $\mathrm{Si}$ substrate by electropolishing. The free-standing PS films were characterized by porosity, thickness and resistivity 
measurements. The average porosity, i.e. the void fraction in the porous layer was measured by gravimetry technique [2].

$P(\%)=\left(m_{1}-m_{2}\right) /\left(m_{1}-m_{3}\right)$

Here $m_{1}$ is Si sample mass before the anodization etching, $m_{2}$ just after etching and $m_{3}$ after the removal of the porous layer by electro-polishing or after a rapid dissolution of the whole porous layer in a $3 \% \mathrm{KOH}$ solution. The resistivity and charge carrier concentration measurements were carried out on the free-standing PS layers attached to dielectric substrate (glass) by using Van der Pauw technique. The In or In$\mathrm{Ga}$ alloy was used as ohmic contact to PS layer. Morphological characterizations of the porous silicon surface were performed by scanning electron microscopy (SEM; JSM-5410LV).

The Au/Porous Silicon/Silicon (Au/PS/Si) structures were fabricated by evaporation of a thin Au film onto the PS surface at room temperature by using the electron-beam technique. The thickness of the deposited Au film was of $150 \mathrm{~nm}$ as obtained by the measurements during evaporation with the aid of a deposition controller (Inficon, Leybold). After anodization the porous silicon membrane on silicon substrate was immersed in a $\mathrm{HCl}$ solution and was exposed to electro-treatment under $d c$ current density (of $40 \mathrm{~mA} / \mathrm{cm}^{2}$ for $20 \mathrm{~min}$ ) to partially oxidize the pore surfaces. The current-voltage (I-V) characteristics, open-circuit voltage $\left(\mathrm{V}_{\mathrm{oc}}\right)$ and short-circuit current density $\left(\mathrm{J}_{\mathrm{sc}}\right)$ of the Au/PS/Si cells and PS/Si structures were measured at room ambient $(300 \mathrm{~K}, 40 \% \mathrm{RH})$ as well as in $\mathrm{HCl}$ electrolyte $(300 \mathrm{~K})$ in measuring cell. The electrolyte with various concentrations of $\mathrm{HCl}$ in water $(1.1-6.0 \mathrm{M})$ was made from $37 \% \mathrm{HCl}$.

The hydrochloric acid-stimulated generation of the open-circuit voltage $\left(\mathrm{V}_{\mathrm{oc}}\right)$ between the contacts to $\mathrm{Au}$ film and PS layer (or Si substrate) was measured directly by a "Thurlby-1503" digital multimeter. The relative humidity $(\mathrm{RH})$ of air was measured with an "Extech-44470" hygro-thermometer. The photosensitive properties of the $\mathrm{Au} / \mathrm{PS} / \mathrm{Si}$ structures were analyzed by measuring of current-voltage characteristics in the dark, daylight and under the tungsten-halogen lamp illumination (about $1.50 \mathrm{~kW} \cdot \mathrm{m}^{-2}$ ). All the investigated structures exhibited very weak photosensitivity. The value of the open-circuit photo-voltage in daylight and under tungsten-halogen lamp illumination was of 1-3 $\mathrm{mV}$. Therefore, $\mathrm{HCl}$-stimulated measurements were performed under daylight illumination.

\section{RESULTS AND DISCUSSION}

SEM micrographs of the porous silicon and $\mathrm{Au} /$ porous silicon surfaces are shown in Figure 1. Here bright islands and relatively dark regions are the top of silicon walls and intervals containing no of porous silicon, respectively. In these experiments we used porous silicon layers with porosity of $65 \%$.

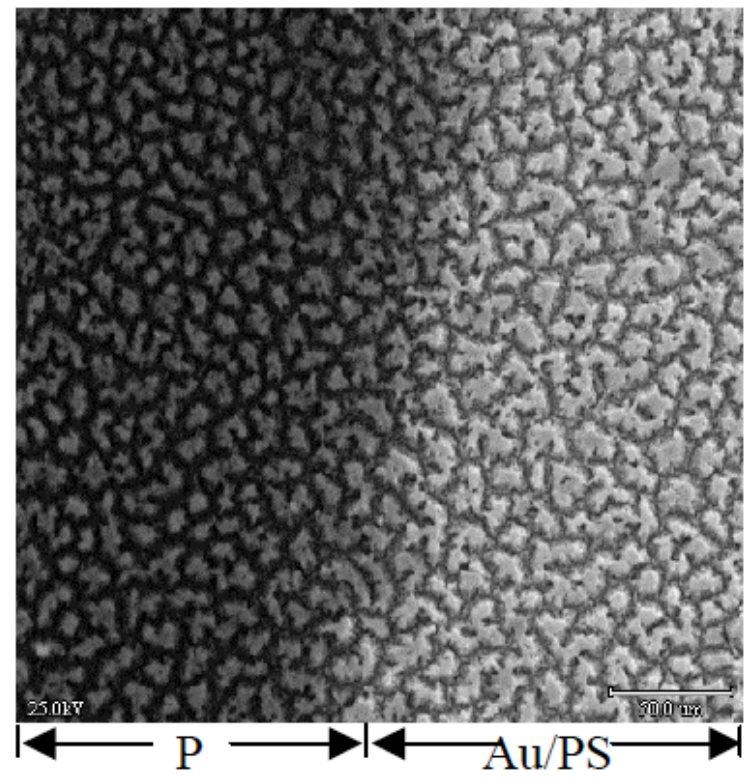

Figure 1: SEM micrograph of porous silicon surface.

The electrical measurements on the free-standing PS layers with $65 \%$ porosity ended up with $\rho=1.8 \times 10^{4}$ $\Omega . m$ for resistivity, $p=9.6 \times 10^{18} \mathrm{~m}^{-3}$ for hole concentration, and $\mu=3.6 \times 10^{-5} \mathrm{~m}^{2} /(\mathrm{V} . \mathrm{s})$ for hole mobility.

Current-voltage characteristics of Au/PS/Si cell as a function of $\mathrm{HCl}$ electrolyte concentration for a hydrochloric acid fuel were presented in Figure 2. Open circuit voltage and short circuit current density as a function of $\mathrm{HCl}$ concentration are shown in Figures 3 and 4 respectively. It is seen that the open circuit voltage decreases (from 650 to $180 \mathrm{mV}$ ) where as the short circuit current density increases (from 10 to 25 $\mathrm{mA} / \mathrm{cm}^{2}$ ) with increasing $\mathrm{HCl}$ electrolyte concentration. The non-linear variation for open circuit voltage and short circuit current density with $\mathrm{HCl}$ concentration can be caused with change of proton concentration penetrating from electrolyte across gold catalyst into porous silicon membrane. It is be noted that the successive placing in and removal of Au/PS/Si cell from $\mathrm{HCl}$ electrolyte is accompanied by the response and recovery of the open circuit voltage with response time of $20-40 \mathrm{~s}$. The control instrumentations showed that for $\mathrm{PS} / \mathrm{Si}$ structures without $\mathrm{Au}$ layer in $\mathrm{HCl}$ 
electrolyte formation of $\mathrm{V}_{\mathrm{oc}}$ and $\mathrm{J}_{\mathrm{sc}}$ of remarkable value were not observed.

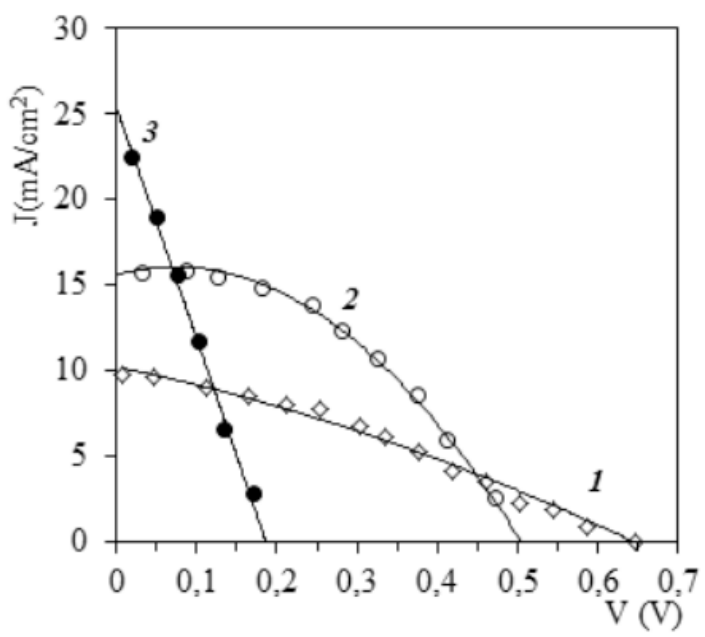

Figure 2: Current-voltage characteristics of $\mathrm{Au} / \mathrm{PS} / \mathrm{Si}$ cell in different $\mathrm{HCl}+\mathrm{H}_{2} \mathrm{O}$ solution:

(1) $1.1 \mathrm{M},(2) 1.7 \mathrm{M},(3) 6 \mathrm{M}$.

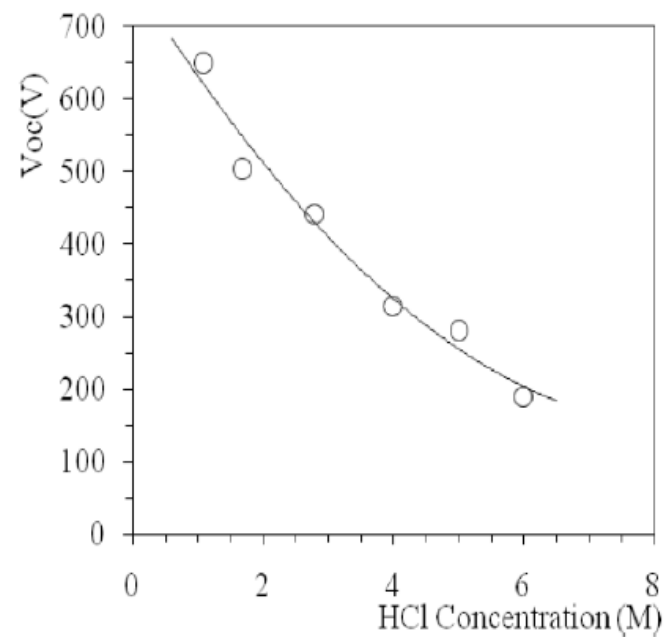

Figure 3: The open circuit voltage of $\mathrm{Au} / \mathrm{PS} / \mathrm{Si}$ cell versus $\mathrm{HCl}$ concentration.

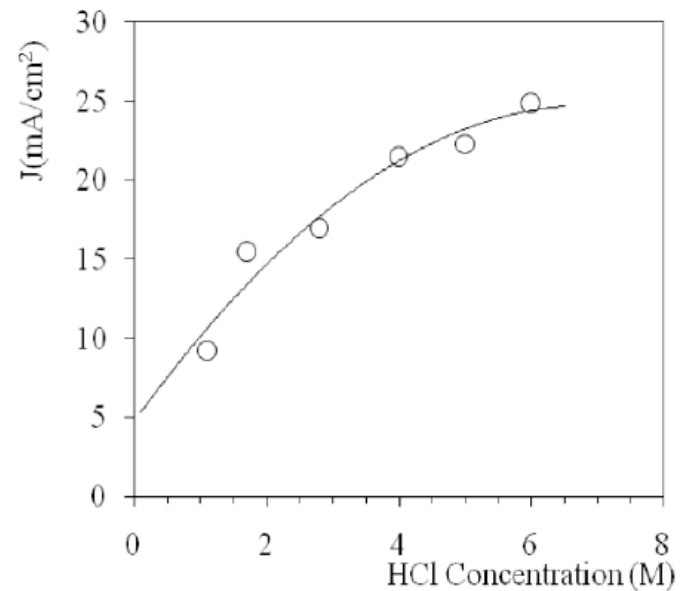

Figure 4: The short circuit current density of Au/PS/Si cell versus $\mathrm{HCl}$ concentration.
Figure 5 shows the power output-current density curves of $\mathrm{Au} / \mathrm{PS} / \mathrm{Si}$ cells depending on $\mathrm{HCl}$ concentration. Results were gained at room temperature with $1.1 \mathrm{M}, 1.7 \mathrm{M}$ and $6 \mathrm{M}$ hydrochloric acid concentration. From the polarization curves we found that maximum of the power density of the single direct hydrochloric acid fuel cell reaches $3.5 \mathrm{~mW} / \mathrm{cm}^{2}$ for $\mathrm{HCl}$ electrolyte of $1.7 \mathrm{M}$.

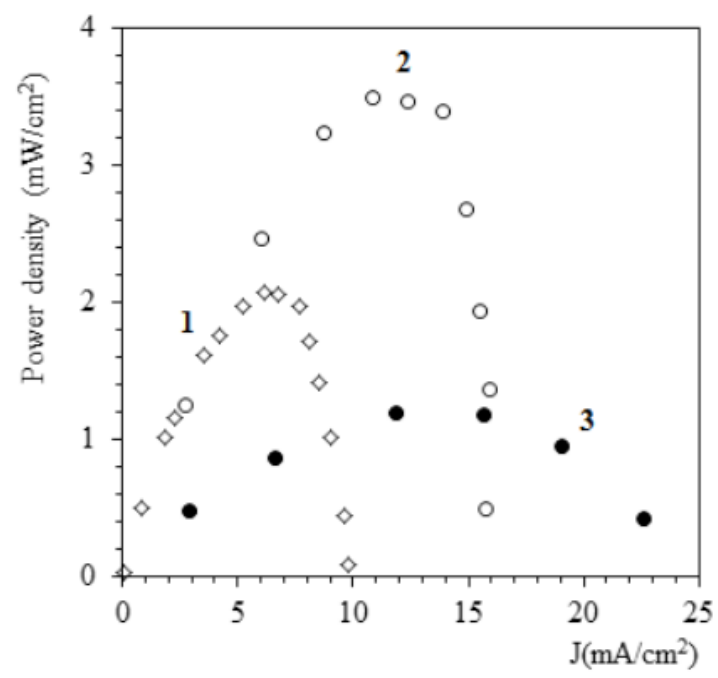

Figure 5: The power density-current density characteristics of $\mathrm{Au} / \mathrm{PS} / \mathrm{Si}$ cell with $\mathrm{HCl}+\mathrm{H}_{2} \mathrm{O}$ electrolyte of $1.1 \mathrm{M}$, (2) $1.7 \mathrm{M}$ and (3) $6 \mathrm{M}$.

As a whole, the following experimental facts related with the change of the electrical characteristics of $\mathrm{Au} / \mathrm{PS} / \mathrm{Si}$ fuel cells with hydrochloric electrolyte were solidly established:

(1) Formation of the open-circuit voltage (up to 650 $\mathrm{mV}$ ) under exposition by $\mathrm{HCl}$ solution was observed for $\mathrm{Au} / \mathrm{PS} / \mathrm{Si}$ structures. At the same time, in the PS/Si structures (without Au film) placed in $\mathrm{HCl}$ electrolyte the electricity generation was not observed.

(2) The values of the open-circuit voltage and maximum of power density depend on the concentration of $\mathrm{HCl}$ electrolyte.

(3) This phenomenon (formation of electricity) is reversible, i.e. for Au/PS/Si cells, placing in and removal from the $\mathrm{HCl}$ solution is accompanied by the response and recovery of $\mathrm{V}_{\mathrm{oc}}$ respectively.

(4) These results allow supposing that the Au/PS/Si structures can be used as direct miniature hydrochloric acid fuel cells.

The mechanism of the generation of the electricity in the metal/PS/Si cells under hydrogen-containing 
ambient has already been proposed [10]. We suggest that in $\mathrm{Au} / \mathrm{PS} / \mathrm{Si}$ cell, similar to direct ethanol fuel cell [11], the Au film and PS layer filled with hydrochlorid acid play the role of the catalytic anode and electrolyte respectively. The interface region between the porous and crystalline silicon (PS/Si), which is very imperfect and stressed, plays the role of the cathode. In the case of $\mathrm{Au} / \mathrm{PS} / \mathrm{Si}$ direct hydrochloric acid fuel cell, when $\mathrm{HCl}$ based fuel is supplied at the $\mathrm{Au}$ anode the following reactions take place [12]

At the anode: $2 \mathrm{HCl}_{(\mathrm{aq})} \rightarrow \mathrm{Cl}_{2(\mathrm{~g})}+2 \mathrm{H}^{+}+2 \mathrm{e}^{-}$

At the cathode: $2 \mathrm{H}^{+}+2 \mathrm{e}^{-}+\mathrm{Cl}_{2} \rightarrow 2 \mathrm{HCl}$

The overall reaction can be expressed as

$2 \mathrm{HCl}_{(\text {aq })} \rightarrow \mathrm{Cl}_{2}+\mathrm{H}_{2(\mathrm{~g})}$

Electrons and protons formed in the Au catalyst film after hydrogen splitting $\left(\mathrm{H}_{2} \rightarrow 2 \mathrm{H}^{+}+2 \mathrm{e}^{-}\right)$, pass through the external circuit and PS layer, respectively and reach the cathode (PS/Si interface) region. Here the hydrogen and electron is recombined producing hydrogen molecule and then hydrogen reacts with chlorine to produce $\mathrm{HCl}$ molecules. Stability of operation for $\mathrm{Au} / \mathrm{PS} / \mathrm{Si}$ cells as a function of storage time in the presence of the hydrochloric acid $(1.1 \mathrm{M})$ was observed for about $140 \mathrm{~h}$. More long-time tests of operation stability of the direct hydrochloric acid fuel cells are currently under investigation.

\section{CONCLUSIONS}

In this study, fabrication and characterization of $\mathrm{Au} / \mathrm{PS} / \mathrm{Si}$ type direct hydrochloric acid fuel cell has been presented. The performance of the fuel cell was measured at room temperature by supplying hydrochloric acid electrolyte. The test results confirm that the cell generated the open-circuit voltage of 650 $\mathrm{mV}$ and maximum power density of $3.5 \mathrm{~mW} / \mathrm{cm}^{2}$ using $\mathrm{HCl}$ solution $(1.7 \mathrm{M})$ as fuel. These results demonstrate the feasibility of development of low-cost small Au/PSbased fuel cells for portable electronic and medical applications

\section{ACKNOWLEDGEMENT}

This work was supported by STCU Grant no: 1585

\section{REFERENCES}

[1] Lu CG, Wang CY, Yen TY, Zhang X. Development and characterization of a silicon-based micro direct methanol fuel cell. Electrochemical Acta 2004; 49: 821-8. http://dx.doi.org/10.1016/j.electacta.2003.09.036

[2] Dzhafarov TD, Aydin SA. Nano-porous silicon-based mini hydrogen fuel cells. In: Manzanera M, Ed. Alternative fuel. Rijeka (Croatia): Intech 2011; pp. 309-45.

\section{http://dx.doi.org/10.5772/25272}

[3] Aravamudhan S, Rahman AR, Bhansali S. Porous silicon based orientation independent, self-priming micro direct ethanol fuel cell. Sensors Actuators A 2005; 123-124: 497504.

http://dx.doi.org/10.1016/..sna.2005.03.069

[4] Gold S, Chu K, Lu C, Shanon MA, Masel RI. Acid loaded porous silicon as a proton exchange membrane for microfuel cells. J Power Sources 2004; 135: 198-203. http://dx.doi.org/10.1016/j.jpowsour.2004.03.084

[5] Anderson EB, Taylor EJ, Wilimski G, Gelb A. A highperformance hydrogen/chlorine fuel cell for space power applications. J Power Sources 1994; 47: 321-8. http://dx.doi.org/10.1016/0378-7753(94)87011-X

[6] Gelb A. $\mathrm{H}_{2} / \mathrm{Cl}_{2}$ fuel cells for power and $\mathrm{HCl}$ productionchemical generation. United States patent US 5041197. 1991.

[7] Shibli SM, Noel M. Platinum - iridium bimetal catalyst-based porous carbon electrodes for $\mathrm{H}_{2} / \mathrm{Cl}_{2}$ fuel cells. Int J Hydrogen Energy 1993; 18: 141-7. http://dx.doi.org/10.1016/0360-3199(93)90200-T

[8] Dzhafarov TD, Oruc Lus C, Aydin Yuksel S, Caliskan M, Yesilkaya SS. Au/Porous silicon-based sodium borohydride fuel cells. Int J Energy Res 2010; 34: 1386-92. http://dx.doi.org/10.1002/er.1680

[9] Dzhafarov TD, AydinYuksel S. Porous silicon-based direct hydrogen sulphide fuel cells. J Nanosci and Nanotechnol 2011; 11: 9012-5. http://dx.doi.org/10.1166/jnn.2011.3456

[10] Dzhafarov TD, Oruc C, Aydin S. Humidity-voltaic characteristics of Au-porous silicon interfaces. J Phys D Appl Phys 2004; 36: 404-9.

http://dx.doi.org/10.1088/0022-3727/37/3/016

[11] Basu S. Fuel science and technology. New York: Springer 2007.

[12] Vidakovich-Koch T, Martinez IG, Kuwerta R, Kunz U, Turek $\mathrm{T}$, Sundmacher K. Electrochemical membrane reactors for sustainable chlorine recycling. Membranes 2012; 2: 510-28. http://dx.doi.org/10.3390/membranes2030510 